\title{
特集 冠循環
}

\section{冠 拡 張 薬}

細 野 清 士*

\section{はじめに}

冠状動脈を昖張する薬剤が冠昖張薬である が，心筋への酸素供給量を増して心筋代謝を改 善する目的に使ら薬剂を冠拡張薬と総称してい る。

\section{冠拡張薬の作用機序}

冠循環には自動 調 節（autoregulation）があ る。心筋に酸素欠乏が括こると，心筋内で ATP が分解されて AMP となり， AMP は心 筋細胞膜にある $5^{\prime}$ nucleotidase によって dephospholylate されて adenosine となり，心筋細胞 外へ出る1)。この adenosine が冠状動脈を拡張し て冠血流量を増し，それによって adenosine が 洗い出されれば冠血流量は元にもどる。すなわ ち, 冠状動脈を拡張する mediator は adenosi$\mathrm{ne}^{2)}$ である。冠循環の自動調節に関与するのは 冠状動脈の小分枝で，大きな分枝は関与しない といわれる。自動調節の最も著しい現われは, 冠状動脈を一過性に閉塞した後に解放した時に 現われる反応性充血（reactive hyperemia）で ある3)。また Kirk \& Honig ${ }^{4) 5)}$ によれば，左室 壁では血流量, 酸素張力 $\left(\mathrm{Po}_{2}\right)$, 代謝に外膜 側から内膜側への勾配があるといら。そのため に内膜側の心筋は血流量が不足して虚血性であ り，内膜側では予備血管が多く開いた状態にあ るといら。

冠循環の自動調節にもかかわらず，冠状動脈

*慶応義塾大学医学部内科
による酸素供給量が心筋の酸素需要量を満たし えない状態が冠不全である。冠拡張薬の最もよ い適応は冠不全であり，その代表的なものは狭 心症である。冠拡張薬は動物実験では冠血流量 を増し，心筋代謝を改善するが，正常犬に現わ れた薬理作用がそのまま冠状動脈硬化のある虚 血性心疾患に現われるかどらか疑問である。虚 血性心疾患では左室心筋全体の冠不全よりも局 所的の冠不全が問題となる。冠状動脈硬化を基 礎としておこる急性および慢性の冠不全を改善 することはなかなか困難である。狭心症の発作 に対しては Nitroglycerin などの亜硝酸剂以外 は有効でなく，心筋硬塞の狭心痛には冠拡張薬 は無効であるのが現状である。

\section{亜硝 酸 剂}

冠拡張薬として古くから用いられ，その主な ものは表 1 に示す通りである。曲硝酸剂の本質

表 1 亜硝酸剤

\begin{tabular}{|c|c|c|}
\hline 薬 品 名 & 商 品 名 & 用法および用量 \\
\hline Amyl nitrate & 亜硝酸アミル & \\
\hline Nitroglycerin & ニトログリセリン & $\mathrm{mg}$ 舌下 \\
\hline $\begin{array}{l}\text { Trolnitrate } \\
\text { phosphate }\end{array}$ & Methamine & $\mathrm{g}$ 考 \\
\hline $\begin{array}{l}\text { Erythrol } \\
\text { tetranitrate }\end{array}$ & Cardilate & 下 \\
\hline $\begin{array}{l}\text { Isosorbide } \\
\text { dinitrate }\end{array}$ & $\left.\begin{array}{l}=ト ロ-ル \\
カ ル ハ ゚=ー ル ~\end{array}\right\}$ & $\begin{array}{l}\text { g 舌下 } \\
\mathrm{g} \text { 内服 }\end{array}$ \\
\hline $\begin{array}{c}\text { Pentaerythritol } \\
\text { tetranitrate }\end{array}$ & $\begin{array}{l}\text { ハセスロール } \\
\text { ペクトレックス }\end{array}$ & $\begin{array}{l}20 \sim 60 \mathrm{mg} \text { 内服 } \\
40 \sim 80 \mathrm{mg} \text { 内服 }\end{array}$ \\
\hline
\end{tabular}


的作用は平滑筋の弛緩であり，冠状動脈だけで なく他の動脈, 静脈, 毛細管をすべて拡 張す る。心筋収縮力，心拍数には直接関係しない が，血管抎張によって血圧を下げるので，反射 性に交感神経興奮（心および末梢血管の）を括 こす。

亚硝酸剂特に Nitroglycerin は狭心症の 発作に 対して最も有効であり，古くから使われている が，狭心痛に対する作用機序については議論が ある。Nitroglycerin による冠血流量の増加は 動物実験においても一過性である。 Gorlin'6), Rowe ${ }^{7)}$ は臨床例において冠血流量を $\mathrm{N}_{2} \mathrm{O}$ 法で 測定し, Nitroglycerin 投与後にかえって減少す るのを見ている。したがって Nitroglycerin が 狭心症に有効なのは，血圧を下げて心仕事量を 減ずるためであろらとしている。 Nitroglycerin が心筋代謝を改善するといら説もある ${ }^{8) 99}$ 。

Fam \& McGregor 10)11) は犬で左冠状動脈の 分枝を結禁して実験し， Nitroglycerin は結㷊 部より末梢の retrograde flow を增し, 虚血部 の酸素分圧を高めることを見ている。彼らは Nitroglycerin が冠状動脈の近位部の分枝を拡張 して虚血部心筋への副血行路の血流を増加させ たためとしている。Winbury ら

Nitroglycerin による冠血流量の増加は軽度で一 過性であり，これは主として冠状動脈の小分枝 の拡張によるが，それに続いて冠状動脈の大き な分枝を選択的に長時間（ $7 \sim 12$ 分）拡張し, 冠循環の副血行を増す。その結果冠血流量は全 体としては増加しないが, 冠血流の redistribution を生じ, 内膜側心筋, また虚血部心筋への 血流量を増して有効であるという。 Nitroglycerin が冠状動脈の大分枝を拡張する作用は $\beta$ 受容体遮断薬で block されないから， $\beta$ 受容体

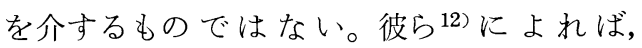
PETN も同様の作用機序を示すといら。

\section{1. 亜硝酸アミル}

狭心症の発作に用いる。揮発性であるから， アンプレ $(0.25 \mathrm{ml}$ 含有 $)$ を折って手早く鼻の先 に持っていって吸入する。速効性（10秒以内に 効き出す）であるが，効果は数分しか続かない （冠血流量の増加はせいぜい 1 分30秒しか続か
ない)。効果が不十分であれば繰り返して用い る。作用時間の短いのと不快な臭いがあるのが 欠点である。

副作用としてはどうき, 降圧, 顔が赤くほて ること, 頭痛などがある。どうきは同時に括こ る心拍数の増加による。降圧, 顔がほてること は末梢血管の拡張により, 頭痛は脳血管拡張に よる脸内圧の上昇による。

眼圧を高めて緑内障を悪化することがあるの で, 緑内障の患者には禁忌である。

\section{Nitroglycerin}

狭心症の発作に対して最も広く用いられる。 $0.3 \mathrm{mg}$ または $0.6 \mathrm{mg}$ 入りの錠剤で舌の上にの せるか舌の下に入れて溶けただけ飲み込ませ る。効果は 1 分位で現われ，30分位持続する。 1 錠で発作が止まらないときは 5 分位の間隔で 繰り返して用いる。狭心症の発作に対しては最 も有効で, しばしば発作のある患者には，携帯 していて発作がおきたらすぐ使えるように指導 する。急性心筋硬塞症, 中間型の狭心発作に対 しては効かないことが多い。

副作用としては頭痛, 起立性低血圧（はなは だしいときは失神)，悪心などがある。頭痛は 脳血管の拡張によって脳内圧が上昇したため で，激しい時はアスピリンなどの鎮痛剂を与え る。起立性低血圧は末梢血管の拡張による。大 量投与でまれにメトへモグロビン血症をおこす ことがある。

眼圧を高めるので緑内障には禁忌である。ま た降圧作用があるので, 急性心筋硬塞症でショ ックの徵があるときは禁忌である。

\section{Isosorbide dinitrate}

商品名ニトロール，カルバニールで $1 \sim 2$ 錠 （ $5 \sim 10 \mathrm{mg}$ ）を舌下錠として Nitroglycerin と 同様に狭心症の発作に用いる。作用は Nitroglycerin よりも弱い（2 錠が Nitroglycerin 1 錠に相当する）が，副作用も少ないので広く用 いられている。また $5 \sim 30 \mathrm{mg}$ 内服を狭心症の 間けつ期に発作の予防の目的に用いる。

副作用，禁忌は Nitroglycerin の場合と同様 である。

4. Pentaerythritol tetranitrate (PETN) • 
表 2 キサンチン郕

\begin{tabular}{|c|c|c|}
\hline 品 & 商 品 名 & 用量および用法 \\
\hline Theophylline ethylendiamine & 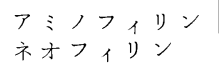 & $\begin{array}{l}250 \sim 500 \mathrm{mg} \text { 静注 } \\
1 \text { 日 } 0.3 \mathrm{~g} \text { 内服 }\end{array}$ \\
\hline Dihydroxypropyl-theophylline & $\begin{array}{l}\text { コルフィ1リソ } \\
\text { モノフィリン } \\
\text { プロフィイリン } \\
\text { ネオフィィリン } \mathrm{M}\end{array}$ & $\begin{array}{l}300 \mathrm{mg} \text { 静注, 筋注 } \\
1 \text { 日 } 0.3 \mathrm{~g} \text { 内服 }\end{array}$ \\
\hline Hydroxyethyl-theophylline & オキシフィリン & $\begin{array}{l}220 \mathrm{mg} \text { 静注 } \\
1 \text { 日 } 0.3 \mathrm{~g} \text { 内服 }\end{array}$ \\
\hline 7-oxyethyl-theophylline & パルマ $=-ル$ & $\begin{array}{l}220 \mathrm{mg} \text { 静注 } \\
1 \text { 日 } 660 \mathrm{mg} \text { 内服 }\end{array}$ \\
\hline 7-chlorethyl-theophylline & ベナフィリン & $200 \mathrm{mg}$ 静注 \\
\hline Choline-theophylline & テォコリン & 1 日 $300 \sim 600 \mathrm{mg}$ 内服 \\
\hline $\begin{array}{l}\text { 7- }(\gamma \text {-diisobutylamino- } \beta \text {-benzoyl- } \\
\text { oxypropyl-theophylline } \\
(\text { TH 24) }\end{array}$ & ベストフィリン & 1 日600 mg 内服 \\
\hline
\end{tabular}

動物実験で $250 \mu \mathrm{g} / \mathrm{kg}$ 静注で Nitroglycerin と 同様の作用機序があるといら年。しかし Nitroglycerin ほど速効性でなく，狭心発作にはあま り有効でない。

商品名八セスロール，ペクトレックスで 1 日 40 $80 \mathrm{mg}$ 内服を，狭心症の間けつ期に発作の 予防に用いる。副作用は少ない。

\section{キサンチン剂}

冠血流量を著明に増加させるので，同時に心 拍数を增し, 心筋酸素消費量を増加させるが, 全体として心筋つ酸素レベルを高めて心筋代謝 を改善する。同時に利尿作用, 気管支拡張作用 がある。 methylxanthine は cyclic $3^{\prime}, 5^{\prime}$ AMP

(cyclic AMP) を不活性化する phosphodiesterase の作用を阻害し，組織中の cyclic AMP の濃度を高めて気管支拡張作用を抏こすとされ ている。心に対する作用にも cyclic AMP の関 与が考えられる。

慢性冠不全患者に狭心発作の予防の目的に用 いる。また気管支喘息あるいは心蔵喘息に合併 した狭心発作, あるいは狭心発作で心不全の徵 があるときに好んで用いられる。主な薬剂と用 量は表 2 の通りである。

\section{アデニン誘導体}

冠循環を自動調節するのが adenosine である とすれば， adenosine その他のアデニン誘導体 の使用は興味がある。その作用部位は冠状動脈 の小分枝と思われる。

ATP (adenosine triphosphate) を急速静注す ると, 一過性に著明な冠血流量の増加, 降圧, 徐脈，過呼吸を生ずるが，その持続はせいぜい 1 分30秒位である。ATP を生食水に溶かして 点滴静注すると, 点滴中は冠血流量の著明な増 加があり，点滴中止とともに消失する。心筋酸 素消費量を増加させずに，心筋の酸素レベルを 高めて心筋代謝を改善する13)。ATP を冠状動 脈内に注入すると，心筋の ATP, phosphocreatine の含量の增加がみられる14)。

adenosine 静注でも ATP 静注と同様の作用 がみられる。

ATP (商品名アデホス, トリノシン) は生食 水または $5 \%$ ブドウ糖に $0.2 \%$ の割合に溶かし て $5 \sim 10 \mathrm{mg} / \mathrm{kg}$ を点滴静注する。また 10〜20 $\mathrm{mg}$ を $20 \%$ ブドウ糖とまぜてゆっくり静注す る。ともに軽度の降圧, 徐脈を伴う。点滴速度 または静注速度が早いと, 降圧, 徐脈が著明と なり，呼吸数の増加もおこり，患者はどらき， 息切れを訴えるから注意を要する。 
狭心症の発作に対しては効果はなく, 狭心症 の間けつ期, 慢性冠不全, 急性心筋硬塞症の回 復期に用いて有効である。ATP 静注はかなり 著明な降圧作用を伴うので, 急性心筋硬塞症で ショックの危険があるときは禁忌である。

ATP 1 日 10 20mg 筋注, 1 日 3 6 錠内 服, adenosine (商品名ボニトン) 1 日 0.06〜 $0.1 \mathrm{~g}$ 内服を冠拡張薬, 心筋代謝賦活剂として, 狭心症の間けつ期, 急性心筋硬塞症の回復期に 用いる。筋注, 内服では降圧, 除哌なとの副作 用はほとんどない。

\section{Dipyridamole}

心筋に酸素欠乏が括こると心筋内の ATP が 分解されて adenosine となり, 心筋細胞外に出 て冠状動脈を抎張する。細胞外に出た adenosine は adenosine deaminase の働きで inosine となり,さらに hypoxanthine となる。Dipyridamole $は$ adenosine deaminase に抑制的に働い て adenosine が inosine になるのを妨げ, adenosine が冠拡張作用を続けるようにする。

$0.2 \sim 0.5 \mathrm{mg} / \mathrm{kg}$ 静注によって冠血 流量を著 明に増加させ, 心筋酸素消費量を増加させない で, 心筋の酸素レベルを高めて心筋代謝を改善 する。軽度の一過性降圧, 徐脈作用がある。冠 血流量の増加は収縮期, 拡張期ともに抢こり, 長時間（30分以上）持続する。しかしもっぱら 冠状動脈の小分枝（末梢冠血管）を拡張するの で，冠血流の再分布はおこらず，副血行を介し ての虚血部心筋への血流量の増加はみられない といら ${ }^{10) 11) 。 W i n b u r y ~} 5^{12)}$ は健常部心筋への 血流量を増し, 虚血部心筋への血流量はむしろ 減少させるので, 不利であるという。長期間に わたって投与すると冠状動脈間の吻合を促進す るといら。

商品名ペルサンチンで, 10～20mg を $2(\%$ \%゙ ドウ糖にまぜてゆっくり静注するか，1日6〜 12錠（1 錠中 Dipyridamole $12.5 \mathrm{mg}$ 含有）を 内服で与える。狭心症の発作に対しては無効 で, 狭心症の間けつ期, 急性心筋硬塞症の回復 期に用いる。心筋硬塞予防の目的で長期間 (3 カ月以上）内服飞試みられている。
静注の場合に一過性に軽度の降圧, 徐脈がみ られるが，それ以外の副作用は少なく，禁忌も ない。

\section{Prenylamine}

$0.2 \sim 0.5 \mathrm{mg} / \mathrm{kg}$ 静注で, 一過性降圧を伴って 冠血流量老增加させ, 心筋の酸素消費量をあま り増加させないで, 心筋の酸素レベルを高めて 心筋代謝を改善する。冠血流量の増加は $1 \sim 2$ 分に過ぎない。他に交感神経遮断, 鎮静作用が ある。

商品名セゴンチンで 40〜 $80 \mathrm{mg}$ 静注, 1 日 225 450mg 内服で与学る。狭心症の間けつ期 に用いて, 自, 他覚的症状を改善し, 発作の回 数を減らして有効である。認むべき副作用はな い。

\section{Flavon 誘導体}

\section{Ef loxate}

強力な冠拡張作用があるといら報告と, 好結 果がえられないといら報告とがあるが，著者は 1 日 $18 \mathrm{mg}$ 内服でかなりの好成績をえた。

商品名レコルジールで 1 日 $18 \mathrm{mg}$ （6 錠）内 服を狭心症の間けつ期，慢性冠不全に用いる。 認むべき副作用はない。

\section{Ghromonar（または Carbochromen)}

軽度であるが長時間持続する冠拡張作用があ り，血圧，心拍数にはほとんど影響を与えな い。冠状動脈の小分枝を拡張し，その作用は強 力で, Chromonar 使用後は反応性充血も現われ ないといら報告もある ${ }^{12)}$ 。また冠状動脈間吻合 を促進する。

商品名インテンザインで, $40 \sim 80 \mathrm{mg}$ 静注, 1 日225 450 mg 内服を, 狭心症の間けつ期, 急性心筋硬塞症の回復期, 慢性冠不全に長期間 連用する。

\section{Papaverine}

Papaverine hydrochloride の形で古くから用 いられる。動物害験で $1 \sim 2 \mathrm{mg} / \mathrm{kg}$ の静注で 大動脈圧の低下, 冠血流量の増加を生ずる。 Nitroglycerin と異なって冠状動脈の大分枝の抵 
抗をむしろ高める12)。

臨床例では冠血流量の増加をみないといら報 告もあるが，大動脈圧を下げて心の負担を少な くする。臨床効果は疑問であるが，Katz ${ }^{15)}$ は 常用量（1日0.06 0. 08g） は過少で, 1 日300 〜400mg を要するといら。大量では悪心, 食思 不振, 頭痛, 便秘などの副作用が多くなる。

\section{その 他}

\section{Verapamil}

$0.1 \sim 0.25 \mathrm{mg} / \mathrm{kg}$ 静注で冠血流量の増加をき たし, 軽度の降圧, 徐脈を伴う。冠血流量の増 加は $1 \sim 2$ 分で最高に達し, 15分以内に元の值 にもどる。冠状動脈の大分枝は拡張させない。 また $\beta$ 受容体遮断薬と似た作用がある。

商品名ワソランで, 1 日120 240 $\mathrm{mg}$ 内服, $5 \sim 15 \mathrm{mg}$ 静注を狭心症の間けつ期に発作予防 の目的で用いる。認むべき副作用はない。

\section{Trimethazine}

Trimethazine dihydrochloride の形で用いら れる。冠血流量を増加させ, 心仕事量を減少さ せる。

商品名バスタレルで, 1 日 6 錠内服を狭心症 の間けつ期, 慢性冠不全に用いる。認むべき副 作用はない。

\section{Oxyfedrin}

冠状動脈を拡張し, 心筋収縮力は強めるが, 心筇の酸化還元電位, ATP, CP レベルは正常 に保つといわれる。

商品名イルダメンで 1 日 $24 \sim 32 \mathrm{mg}$ 内服, 4 $\sim 8 \mathrm{mg}$ 静注を, 狭心症の間けつ期, 慢性冠不 全に用いる。

4.

Khellin, Amplivix はあまり使われず，Amiodarone (商品名 FK 1050), Coralgil 忤製造中 止となったので，省略する。

な打降圧作用を伴った強力な冠拡張薬が 1 〜 2 開発されつつあることをつけ加える。

\section{おわりに}

狭心症の発作に対しては, 冠状動脈の大分枝 を拡張して冠血流の再分配をする Nitroglycerin などの亜硝酸剤だけが有効で; 急性心筋硬塞症 の狭心痛に対しては有効な冠拡張薬がない。

虚血性心疾患に対して, 冠血流の再分配をお こすより強力な冠払張薬が必要であるのか, 冠状動脈の小分枝を拡張する Dipyridamole, Chromonar などの冠拡張薬は無効であるか, な どは今後に残された問題である。

\section{文献}

1) Berne, R.M. and Rubio, R.: Am. J. Cardiol., 24; 776, 1969.

2) Berne, R.M.: Am. J. Physiol., 204; 317, 1963.

3) Coffman, J.D. and Gregg, D.E.: Am. J. Physiol., 199; 1143, 1960.

4) Kirk, E.S. and Honig, C.R.: Am. J. Physiol., 207; 661, 1964.

5) Honig, C.R., et al.: Transmural distributions of blood flow, oxygen tension, and metabolism in myocardium: Mechanism and Energetics of the Myocardium, ed. by G. Marchetti and B. Taccardi, p. 46, S. Krager, New York, 1967.

6) Gorlin, R., et al.: Circulation, 19; 705, 1959.

7) Rowe, G.C.: Am. Heart J., 68; 691, 1964.

8) Honig, C.R., et al.: Am. J. Med., 29; 910, 1960.

9) Kranz, J.C. Jr., et al.: J. Pharmaco. \& Exper. Therap., 102; 16, 1951.

10) Fam, W.M. and McGregor, M.: Circulat. Res., 15; 355, 1964.

11) Fam, W.M. and McGregor, M.: Circulation, 34; 100, 1966.

12) Winbury, M.M., et al.: J. Pharmaco. \& Exper. Therap., 168; 70, 1969.

13) Hosono, K.: Jap. Circulat. J., 27; 159, 1963.

14) Fedelesova, M., et al.: Circulat. Res., 24; 617, 1969.

15) Elek, S.R. and Katz, L.N.: J.A.M.A., 120; 434, 1942. 